\title{
Heirloom of Knowledge: Teacher-Parents and Their Prioritization of the Education of Their Children
}

\author{
Katherine Joyce M. Castro \\ Polytechnic University of the Philippines Santa Maria, Bulacan Campus, Pulong Buhangin, Santa Maria, Bulacan, Philippines
}

Received November 14, 2020; Revised January 11, 2021; Accepted January 28, 2021

\section{Cite This Paper in the following Citation Styles}

(a): [1] Katherine Joyce M. Castro, "Heirloom of Knowledge: Teacher-Parents and Their Prioritization of the Education of Their Children," Universal Journal of Educational Research, Vol. 9, No. 2, pp. 380 - 389, 2021. DOI: 10.13189/ujer.2021.090214.

(b): Katherine Joyce M. Castro (2021). Heirloom of Knowledge: Teacher-Parents and Their Prioritization of the Education of Their Children. Universal Journal of Educational Research, 9(2), 380 - 389. DOI: 10.13189/ujer.2021.090214.

Copyright $\bigcirc 2021$ by authors, all rights reserved. Authors agree that this article remains permanently open access under the terms of the Creative Commons Attribution License 4.0 International License

\begin{abstract}
The study deals with the thoughts and philosophies of the teacher-parents that inspire them to emphasize on the education of their own children. The informants of this study were the twenty (20) primary and secondary teacher-parents in the Division of Bulacan, Philippines who are purposely selected. Each informant has 3-6 children who are at least bachelor's degree holders. This research employs qualitative research design. The study's main tool is a semi-structured interview questionnaire. After the completion of the interviews, all data were transcribed and then analyzed using content analysis. Based on the results of the study, the following findings were noted: securing a better future of their children serves as the greatest motivation for the teacher-parents in sending their children to school; and teacher-parents assured that their children will finish their studies on time by securing the finances for the education of their children. The researcher recommends that the proposed financial scheme be adopted by the teacher-parents to help them in the prioritization of the education of their children.
\end{abstract}

Keywords Education, Teacher-Parents, Education of Children

\section{Introduction}

Education is an essential element for a successful and meaningful future. It is considered as a priced possession any person must have in order to be successful in this world full of competition. According to Denny [1], it "plays a vital role in individuals' life chances, the strength of the intergenerational link acts to limit equality of opportunity and maintain existing inequalities". Thus, most of the parents think that education is one of the best heirlooms they can provide their children to ensure financial stability and better quality of life.

Filipinos generally place high value on education. For them, education is a source of pride and strong foundation of their children's future. [2] Verily, the fundamental law of the land ensures that education is accessible to the Filipino youth through the mandate on the establishment and maintenance of free public education in the primary and secondary levels Moreover, the government puts reality to its function as it extends its utmost effort to widen the Filipinos' access to education. It ensures that every Filipino family is given the opportunity to have college graduates who will help them alleviate themselves from poverty. This has been realized through the implementation of the Republic Act 10931 [3] which is also known as the Universal Access to Quality Tertiary Education. It aims to provide free tuition and other school fees in state-funded universities, colleges and technical-vocational institutions. This act also established the tertiary education subsidy and student loan program while strengthening the unified student financial assistance system for tertiary education.

It is explicitly stated in the 2017-2022 Philippine Development Plan that by the year 2022, Filipinos will 
enjoy greater opportunities to develop their full potential. The Philippines is geared toward becoming a globally-competitive knowledge economy and an upper-middle income country by providing its people with the access to lifelong learning opportunities. Thus, it sees that education is the key to reduce inequalities and poverty particularly in rural areas. The Philippine Development Plan 2017-2022 [4] envisions attaining the following:

To achieve quality, accessible, relevant, and liberating basic education for all, the following strategies will be implemented: (1) Strengthen early childhood care and development programs; (2) pursue full implementation of the K-12 program; (3) strengthen the inclusion programs to reach stakeholders outside the formal education system; (4) develop and improve interventions to keep children in school; (5) continue curricular reforms; (6) enhance teacher competencies.

Truly, the policies issued by the government aim to realize of the 2017-2022 Philippine Development Plan. It only shows that the education sector has clear plans in prioritizing the human capital of the country by providing quality and accessible education for all Filipinos.

The government believes that education plays a big role in changing the lives of its people. Reconstructionism as a philosophy stands for change. According to Parks [5], "it asks teachers to become agents of social change instead of perpetuating the status quo" (p. 46). The curriculum of reconstructionist focuses on students' experiences and considers real social problems such as violence, hunger, international terrorism, inflation, and inequality. Thus, Stern and Riley [6] states that the school and the teachers may be used as instruments of social study to solve these social problems.

Though people believe in the saying that the current socio-economic status of a person is not a hindrance in attaining one's goal in life, Murphy and Tobin [7] believe that poverty affects the academic performance of the students and poor students tend to have poor or average grades only. Moreover, students suffering from poverty may experience limited access to technology, academic resources, and other required school materials. [7,8] Limited exposure to nutritional foods which affect cognitive function and limited vocabulary exposure may further affect the academic ability of the students. This, according to Fine, cited in [9], results to the dissatisfaction from the school experiences of many poor students; thus, pushes them to quit schooling then find employment to help their families financially.

Al-Matalka [10] believes that parents have a strong influence on the lives of their children. The children's interests, education, and goals are influenced by their parents. Through parental love, care, support, and guidance at home, children could be successful in their education and, later on, in life. Vellymalay [11] believes that "a child's capability to succeed in school depends on how successfully the child is managed by his/her parents at home. A home is an avenue where the child can learn the skills, attitudes, and behavior which could mold him/her into a productive and successful student" (p. 146). It is at home where the children should feel loved, supported and cared for first. It is at home where the child should be taught right values, positive attitude, and appropriate behavior which later on be enhanced in school. It is at home where they should learn the basic knowledge and skills, having their parents as their first teachers.

Parental involvement in education does not rely solely on the financial support to children's education but also in appreciating their children's achievements and providing a positive educational environment at home. Thus, parental involvement in a child's education should be defined as their support and guidance in a child's learning experiences starting at home and continued to school.

Among the educated and working parents, the teachers are the ones who are expected to understand the greater value of education and parental involvement in the child's education. According to the Republic Act No. 4670, also known as the Magna Carta for Public School Teachers [12], "teachers shall mean all persons engaged in classroom teaching, in any level of instruction, on full time or part time basis, including guidance counselors, school librarians, industrial arts or vocational instructors and all other persons performing supervisory and/or administrative functions of schools, colleges and universities; but shall not include school nurses, school physicians, school dentists and other school employees". It can be observed that most of the children of the teacher-parents usually do well in school. Aside from the good choice of school, teachers know well the relations between their children's academic skills possible future job options. They may assess their own children's strengths and take this as a reference in guiding them in choosing their college degree. These factors definitely show that parents who are teachers have various advantages in rearing their own children.

This study aimed to provide information about the education viewpoints of teachers as parents. The researcher would like to unravel the thoughts and philosophies of the teacher-parents that inspire them to prioritize the education of their own children and to clearly show how they differ from parents of other professions or endeavor. Furthermore, this study would like to present the experiences of the teacher-parents in sending their children to school. Generally, this study would want to bring to light the philosophies that guide the teacher-parents in prioritizing the education of their children.

\subsection{Research Statement}

Despite the struggling economic status of the family, and amidst other social considerations, teacher-parents 
consider the education of their children as top priority expenditure.

\section{Integrated Review of Related Literature and Studies}

A review of related literature is presented in this part of the study. The realities discussed and conferred by these written materials served as a foundation and added information to better analyze the findings of the study.

\subsection{Economic Status and Financial Difficulties of Teachers}

Teachers do lots of work at school. They even sacrifice their own time and money just to provide a good quality of education to the students. This is why teachers should receive just compensation for their hard work.

The government ensures to promote and improve the social and economic status of public-school teachers, their living and working conditions, their terms of employment and career prospects. In fact, the Executive Order No. 201, s. 2016 [13], which is titled "Modifying the Salary Schedule for Civilian Personnel and Authorizing the Grant of Additional Benefits for Both Civilian and Military Uniformed Personnel" was signed by President Benigno S. Aquino III. This E.O. No. 201 was implemented to attract, retain, and motivate a core of competent civil servants. The Fourth Tranche Salary Standardization (SSL) Law was implemented on January $1,2019$.

However, this Salary Standardization Law of 2016 did not apply to the six informants of the study because these informants are either retired teachers or teachers from private schools.

Aside from the higher net take-home pay, teachers also enjoy different bonuses and incentives. According to Llego [14], one of them is the Personnel Economic Relief Allowance (PERA) which amounts to $\mathrm{PhP} 2,000$ per month. In addition, the government also grants teachers annually with mid-year and year-end bonuses which are equivalent to one (1) month basic salary, the Productivity Enhancement Incentive (PEI) which amounts to $\mathrm{PhP}$ 5,000, clothing allowance which amounts to PhP 5,000.00, Productivity Incentive Benefit (PIB) equivalent to $\mathrm{PhP}$ 2,000.00, cash gift equivalent to $\mathrm{PhP} 5,000$, and the Performance-Based Bonus (PBB) which ranges from $\mathrm{PhP}$ 35,000 (highest) to PhP 5,000.00 (lowest) depending on the performance of each delivery unit.

Despite the salary increments provided by the government to the Filipino teachers, they still experience financial difficulties and problems caused by inflation and higher cost of living in the country.

According to Philippine Statistics Authority (PSA), a family of five needs a minimum income of PHP 7,377, on average, to meet the basic food needs that can satisfy the nutritional requirements to ensure a person's productivity economically and socially. [15] Moreover, a family of five must have a minimum income of PHP 10,481, on average, to meet both basic food and non-food needs of the family which includes clothing, electricity, fuel, light and water, housing, rental of occupied dwelling units, transportation and communication, health and education expenses, non-durable furnishing, household operations and personal care and effects. [16] Moreover, the PSA releases a measure that shows the deprivations on thirteen (13) identified indicators such as electricity, housing materials, tenure status of dwelling, sources of water supply, toilet facility, ownership of assets, health insurance, food consumption, hunger, working children not in school, underemployment, educational attainment, and school attendance. This measure is called the multidimensional poverty index (MPI). The study revealed that among the thirteen indicators educational attainment had the largest share to the overall deprivation (MPI) with 59.3\% in 2016 and $49.4 \%$ in 2017.

Malipot [17] highlights that according to the Department of Education Secretary, Leonor Briones, public school teachers have the tendency to borrow money is 50 percent higher compared to other government employees. In addition, she noted that teachers avail so many loans despite of enjoying two-month paid vacation, clothing and chalk allowances, and bonuses. She also noted that before, teachers borrow money to pay for the tuition of their children. But now, based on initial findings, teachers spend on a variety of things including travel abroad.

[18] However, Teacher's Dignity Coalition Chairman Benjo Basa seemed to disagree with Secretary Briones's statements. He mentioned that teachers borrow money because of necessity like house rent, education, health, materials and supplies for daily lessons and other essentials which the government failed to provide for them.

[19] Moreover, other factors that drive public school teachers to be indebted are more complicated than simple lack of financial awareness. These are also because of late salaries for newly-hired teachers and lack of government financial support for educational equipment like projectors, laptops, markers and even chalk.

\subsection{Financial Literacy}

According to Kenton [20], financial literacy is the education and knowledge in managing finances, money and investing. Financial literacy helps individuals to become self-sufficient and achieve financial stability. The lack of financial literacy can lead to poor financial decisions and large amount of debts.

[21] In attempt to help, Bangko Sentral ng Pilipinas Governor Nestor Espenilla Jr. stated that BSP has 
launched a nationwide financial literacy program for public school teachers which is about money management.

The government agrees in the importance of financial literacy among its people. This has been realized through the implementation of the Republic Act No. 10922 [22], also known as Economic and Financial Literacy Act. This act was implemented because the State believes that the growth potential of the country is through the well-thought of financial decisions of financially literate people. Thus, to conduct consciousness-raising on economic and financial literacy, the second week of November of every year has been declared as Economic and Financial Literacy Week.

Moreover, the State also implemented the Republic Act No. 10679 [23], also known as Youth Entrepreneurship which aims to instigate the entrepreneurial spirit among young Filipinos as well as support and promote the growth of young entrepreneurs nationwide. This act will surely help in producing a great number of entrepreneurs in the future which in the longer run will help in the finances of their families and the growth of the economy.

According to Malipot [24], even the DepEd Secretary Leonor Briones considers the importance of financial literacy to both learners and teachers as the DepEd continues to integrate its concepts in the $\mathrm{K}$ to 12 curriculum. In fact, Secretary Briones mentioned that with the help of their partners, the DepEd has been training trainers of the Financial Literacy Education (FLE) for teachers, which will be integrated in their respective classes.

\subsection{Importance of Education}

Parents believe in the importance of education in the lives of people. According to Occupational Outlook Quarterly [25], getting a college degree will help individuals develop qualities such as initiative, willingness to learn, and organizational ability. Also, the skills needed for work are often acquired through formal education. Thus, education is needed for an individual to be well-developed so he can be considered employable.

That is the reason why every country is investing in the education of its people. According to Machlup [26], "education is commonly regarded as the major form of investment in human resources" (p. 3). Investing in the education of people can increase the labor force's productivity by developing the learner's intellect and over-all quality of life.

Rubinfield and Pindyck [27] mentioned that human capital is the knowledge, skills, and experience that make an individual more productive and will make them able to earn a higher income through at their lifetime. If a person goes to college or graduate school, take postgraduate courses, or enroll in a specialized job training program, that person is investing in human capital. Thus, the finances, time, effort that one invests to build one's human capital will pay off in the form of more rewarding or high-paying job opportunities.

Synder and Nicholson [28] said that workers bring different skills and attributes in their respective jobs. The basic education (elementary and secondary) is the foundation of human capital; it is where the students learn the basic skills. College and university courses, on the other hand, offer general and professional skills which they may use in their future jobs. Other types of formal education may also enhance human capital by providing training in specific tasks.

\section{Methodology}

The qualitative research method was applied in the study on the premise that this is the most appropriate method.

The researcher considered the Division of Bulacan as the locale of her study. This study used purposive sampling technique in selecting the informants. Twenty teachers were identified to provide the necessary information. The first criterion for the sample is that each person must be teaching or must have taught in primary or secondary school. Second, each informant must have teaching rank as Teacher I- Principal IV. Third, each informant should have 3-6 children who have graduated from college. The informants should also be narrowed into teachers who are retired or who are 50 years old and above. This supports the idea that these teacher-parents are practicing their profession and its educational practices and theories are products of her wide experience. All were located through the word of mouth and snowball sampling.

Semi-structured interviews were conducted in person and each of them typically lasted for 30 minutes. The goal of semi-structured interviews is to openly explore the topic of interest. This was also conducted to encourage the teacher-parents to share their personal stories on the topic.

After the completion of the interviews, all data were transcribed and then analyzed using content analysis. The researcher independently categorized and coded the information through line-by-line analysis and consolidated those into salient themes.

\section{Results and Discussion}

The succeeding discussion presents the generated themes based on the thematic analysis employed by the researcher in analyzing the data through transcribed interview transcripts.

\subsection{Teachers in School, Parents at Home}

Many believed that teaching is the noblest profession. 
Goode [29] stated that "teaching demands commitment of one's life to one's potential, looks beyond self to others, and is working for and with society in the preparation and advancement of the race" (p. 195). It requires a person who is willing to give his time, effort, energy, and love to stay in what they call vocation. They are the modern heroes. They have the power to inspire and develop the young members of the society. However, most of the time, teachers' efforts are not compensated by competitive salaries compared to other professions. Thus, most of them are living simple lives.

Teacher-parents and their spouse strive hard to support the majority of the family's expenditures. The teacher-parents' salary and their other sources of income are sufficient for their family's expenditures. The informants' family income ranges from Php 9,000.00- Php $60,000.00$. All of the family expenses do not exceed their family income. However, staying in a country with a very high cost of living is an additional challenge for these informants. Though the informants do not live a luxurious life, they do not oblige their children to contribute to the family income. They let their children have the freedom to spend their own money in their expenses and needs. They also allow them to start their own family and become responsible parents. TP 6 said, "I do not meddle on their finances, Ma'am. When my eldest worked at UPBC, his first salary was given to me. I accepted it but I said if he needs it for his allowance I will give it to him. My husband asked me to return the money. According to him, we should not intrude in their income since we can still work. So, it became our rule - that we will not give our children any responsibility. Now, my children have their own houses. It is only my second child who is with us at home."

Aside from teaching, parenthood is another noble job. It is considered to be the greatest among all professions. Parents do not have any day offs, salaries, nor bonuses. Therefore, being a teacher and a parent at the same time is the most commendable job. It is only accepted by strong and brave people.

Being a good teacher is not an assurance that one will be a good parent or vice versa. Keeping a good reputation and relationship with both your students and children is a very challenging task - most especially if you have three to six children at home and more than forty students in school. The teacher-parents were able to maintain good relationships with their children by establishing friendship with their children. In the words of TP 4: "My relationship with my children is a typical one. We are like buddies/friends to whom they can voice out their feelings and their problems." This helps them to become closer with their children.

Moreover, they consider themselves as devoted teachers. In the words of TP 20: "I am really devoted. I come to school on time. I see to it that my pupils learn something from the whole day of discussion. What I usually do is that after I teach the lesson, I give seat works to find out if they understand our discussion. If not, teach them again until they master it." They are very serious and dedicated with their job. They also consider their students as their own children; thus, considering themselves as the second parents in school. TP 7 said, "As what they say, I am a mother to my students. I am not only a teacher, nor an educator, I am their mother."

\subsection{When Teachers Become Parents}

Researchers believe that most of the professionals have difficulties in adjusting their values in their work when they become parents. This becomes the advantage of teachers since they are dealing with children both at work and at home. Teacher-parents keep their characters of being disciplinarian at home. They believe that setting rules and establishing their roles as parents helps in rearing their own children. However, there are also teacher-parents who remained cool and democratic. They gave their children freedom to express their thoughts and maintained constant communication with them.

Teacher-parents agreed that constant communication with their children is important most especially with regard to their education. The teacher-parents converse with their children almost every night. They usually ask their activities at school, home works, and projects. TP 4 said, "It needs to be constant- communication with your children most especially if they have problems. You need to help them and know (it). Go to school and know what is the problem of the child. This is what lacks in many parent(s). You ask them to come to school to tell them the situation but they do not come- that this is our problem. We do home visitations for those who do not come- it is difficult. We send letters for those who are not coming and despite that, they would still not come."

Aside from guiding the children, another task of a parent is managing the finances of the family and securing that there is a stable finance for their children's education. Teacher-parents agreed that they should put the basic needs as the top priority of the family's expenditures. These basic needs include food, electricity, water, and the education of their children.

Moreover, they do not spend too much on things that are not important such as going to malls, recreation activities and the likes. In the words of TP 10: "I am spending on what they say the needs- basic needs- food, electricity, water, and nothing more. The basic need is the priority. I am doing, of course, correct spending. I do it correctly. Since then because as I have told you, Katherine, even if you ask my colleagues, I am not fond of going to malls. What you have, budget it. Even you have a very high income but you do not spend it wisely nothing will still be left." The teacher-parents exhibited their prioritization of education by securing the finances for the education for their children. They have revealed the different ways that they did such as availing different educational plans, managing the finances properly, and 
lending money from different loan providers. TP 15 said, "While the enrollment date is still far, I am already renewing my loan. My children's age gap from each other is not that wide- 30 years old then 29,27 , they are in succession. Before when I was still a new teacher I do not believe that teachers are members of "London" (laugh)"loan dito, loan doon". I do not believe that. But, when I became a teacher, it is really true that loan is continuous. I became a member of "London". Now, I no longer have loans because our finances have become more stable."

\subsection{Educators' View on Education}

The teacher-parents, compared to other kinds of parents, have better understanding of the importance of education in the lives of people. The informants revealed that they see education as provider of lifetime skills; both in their professional and personal life. In the words of TP 4: "Education provides lifetime skills to students that will help them to become self-reliant. to become responsible citizen(s)." The informants also agreed that education serves as social equalizer. This helps people to alleviate themselves from the current social class. TP 7 said, "I think it is education that could provide, like what they say, not only a better future but a certain future for my children, right? Because when you are educated there are more chances that you will be employed. And when you are employed your future will be more certain, right?" This will help their children to live a successful and independent life in the future. Lastly, education helps people to become assets of the society. People are trained with skills and values needed to develop a better society through formal education.

Teacher-parents were motivated to send their children to school because of the hardships that they have experienced before. In the words of TP 11: "My basis in sending my children to school was my parents' philosophy. They were illiterate but they try to send their five children to school. So, for them we should not imitate their life- and that became my basis in life too. I told my children to study despite poverty. I am crying again (laugh). There was a time that my life was really hard. I experienced having loans just to... But with God's mercy, it is very fulfilling for a parent that my four children finished their schooling. It is really a great accomplishment. I am crying. No, I am just... If I would turn back time and recall our life, we would find that we were so poor. But in God's mercy we were able to overcome it. He never left my side. That's it." They believe that education will help their children to become skillful and knowledgeable people who are employable. Having a better job will help them to uplift their socioeconomic status. They also believe that education is the best heirloom that they can give to their children. TP 18 said, "As the saying goes education is the only heirloom that parents, especially the poor ones, can give to their children. That is one. Second is as we all know many educated nowadays, thus, studying can bring them to the same pace with others in terms of employment. The best motivation is your vision that when you leave them, they have strong foundation and they can stand on their own." Moreover, this gives them a great relief when they leave their children and are already on their own. Education will help their children to be independent in raising their future family.

The informants showed prioritization of the education of their children by getting involved with it. In the words of TP 4: "Of course, follow-up. It should not always be just the teachers. You should guide them too like in doing their assignments or projects. So, constant communication with the children is important. This has become a problem, not only isolated, but a prevalent one in our school. Parents pass on the responsibility that they have to their children to the teachers. That is common in public schools. But it should not be the case, it is important that they are partners, right? Parents should be partners in the education system. It is necessary." Despite the busy schedule of the informants they still managed to help their children in their school works. They were able to use their professional skills in guiding them in doing their assignments, projects, research paper, and the likes. They also guide their children in choosing their courses and future careers. Lastly, as teachers, they have in depth understanding of the importance of the parental involvement in children's academic performance.

\subsection{Beating All Odds}

Being a teacher and a parent at the same time is the most challenging task. However, it is still advantageous for the teacher-parents since they can use their professional skills in rearing their children. They consider the finances as their major problem in sending their children to school. In the words of TP 13: "Like what I said, it maybe the finances. It is because as what I have told you our salary was not enough, in other words, we get stressed because we do not know where we will get the next payment for the tuition fee. So, we let our children understand that they cannot celebrate their debut because we do not have anything to spend and we need to prioritize their studies. Then, I explain to her that our income is not enough in other words we have to double our effort to work so the children will realize that they need to study hard. We experienced difficulty because the three were (in college) at the same time just in different levels." They managed this problem through loans and their unending faith in God. In the words of TP 15, "It is really just prayers. Only prayers and also my husband and I are talk to each other that it is only a challenge for us. As what I have said, we attend the mass. It is mentioned at the mass, in the bible and in church, that God will not give you any challenge that you cannot surpass." TP 7 said, "Our small savings went to it. If we have saved already for schooling- the education of our children- our savings were used for our basic needs. There were instances that 
we loan. We availed loans. The teacher is from London." There are also informants who considered the safety of their children as a problem. In the words of TP 10, "The burden of a parent is always on waiting for the children to come home to ensure their safety. As what I tell their professors- the teachers of my children, they wouldn't believe that they leave home early in the morning and take a bath even though they are sleepless. Thus, I want to see them come home safe." However, they managed these problems by using their professional skills in understanding their children's behavior and their knowledge on the proper way of settling the problems in school.

\subsection{Legacies of the Teacher-Parents}

The informants considered the success of their children as their success too, thus, they are willing to do everything just to give them a comfortable life.

The success of a person is usually associated with money, status, and power. In this study, the informants revealed that their children are considered successful because they became responsible students and were able to finish their studies. In the words of TP 6: "I am happy whenever someone compliments me that I was able to make my children finish their studies. My parents had done the same thing to me and my other five siblings. All of our pictures were framed and hanged on the wall. My parents are boastful because they framed our pictures. Whenever someone would come to our home, they would ask if all of their children are all professionals and they would answer yes. Thus, I followed them when my children finished their studies, I feel successful too because my children have attained what I have attained." They also believe that their children are successful because they landed to good-paying jobs and were able to share their income to the family.

\subsection{Proposed Financial Schemes}

Based on the results of the interview with the teacher-parents, the researcher proposes a financial scheme for teachers. These financial schemes will help the teacher-parents in their budget planning. In this proposal, the teachers can use the given templates in order to properly assess and manage their finances to help them refrain from borrowing money just to support the education.

Teacher-parents must start with managing the income and expenses first. Then, they may create a good investment plan for the education of their children.

The financial planning scheme consists of the following: monthly cash flow budget, family budget plan, and investment plan.

Table 1. Monthly Cash-Flow Budget Template

\begin{tabular}{|c|c|c|}
\hline \multicolumn{2}{|c|}{ Monthly Cash Flow Budget } & \multirow{2}{*}{ Month } \\
\hline & Calculation & \\
\hline \multicolumn{3}{|l|}{ Income \#1 } \\
\hline \multicolumn{3}{|l|}{ Income \#2 } \\
\hline \multicolumn{3}{|l|}{ TOTAL MONTHLY INCOME } \\
\hline \multicolumn{3}{|c|}{ NEEDS } \\
\hline Monthly Needs Budget & Monthly Income $x 50 \%$ & \\
\hline \multicolumn{3}{|l|}{ Utilities } \\
\hline \multicolumn{3}{|l|}{ Groceries } \\
\hline \multicolumn{3}{|l|}{ Mortgage or Rent Payment } \\
\hline \multicolumn{3}{|l|}{ Auto Fuel / Transportation } \\
\hline \multicolumn{3}{|l|}{ Insurance } \\
\hline \multicolumn{3}{|l|}{ Other Necessities } \\
\hline TOTAL NEEDS & Should not exceed monthly needs budget & \\
\hline \multicolumn{3}{|c|}{ WANTS } \\
\hline Monthly Wants Budget & Monthly Income $x 30 \%$ & \\
\hline \multicolumn{3}{|l|}{ Weekly Discretionary Cash } \\
\hline TOTAL WANTS & Should not exceed monthly wants budget & \\
\hline \multicolumn{3}{|c|}{ DEPT PAYMENT AND SAVINGS } \\
\hline $\begin{array}{c}\text { Monthly (Debt Payment) Savings } \\
\text { Budget }\end{array}$ & Monthly Income $x 20 \%$ & \\
\hline \multicolumn{3}{|l|}{ TOTAL SAVINGS } \\
\hline SURPLUS or SHORTAGE & $\begin{array}{l}\text { Monthly Income - Total Needs - Total Wants - Total } \\
\text { Savings }\end{array}$ & \\
\hline
\end{tabular}


Monthly Cash-Flow Budget Template. According to Miller [30] Elizabeth Warren and Amelia Warren Tyagi (2006) introduced a budgeting system also known as "50/30/20 rule" as a way to divide and save one's post-tax income based on needs, wants and savings. Warren and Tyagi [31] stressed that one will be able to achieve his lifetime financial goals if he maintains the spending in three broad categories within certain limits.

Yates [32] presented a Monthly Budget Worksheet which an athlete may use to create his own financial plan. The researcher believes that this financial scheme may also be helpful for the teacher-parents in assessing their family's financial profile. Moreover, by following the "50/30/20" rule in budgeting the family income, the teacher-parents will be able to achieve their family financial goals.

Family Budget Plan. Figure 2 presents the template for the family budget plan. This aims to assess the monthly financial profile of the teacher-parent's family. This includes tables for the family income, fixed expenses, variable expenses, debt, and savings. The first box is the Monthly Take Home Pay. It is composed of the amount of income that each earning family member contributes to the family income and/or other sources of income. The second box contains the Fixed Expenses which cannot be easily changed and are usually spent on a regular basis. Some examples of fixed expenses are mortgage/ rent, utilities, water, electricity, internet, phone, and tithes. The third box contains the Variable Expenses. These are expenses that can change depending on the rate of consumption. Some examples of variable expenses are gas, entertainment, dining out, clothing, health, personal care, and groceries. The fourth table contains debts, if there is any. Some examples of this are debts from the credit cards, GSIS loans, and car payment. The last table contains the savings of the family. This may contain the emergency fund, retirement, college savings, and other investments.

Table 2. Family Budget Plan

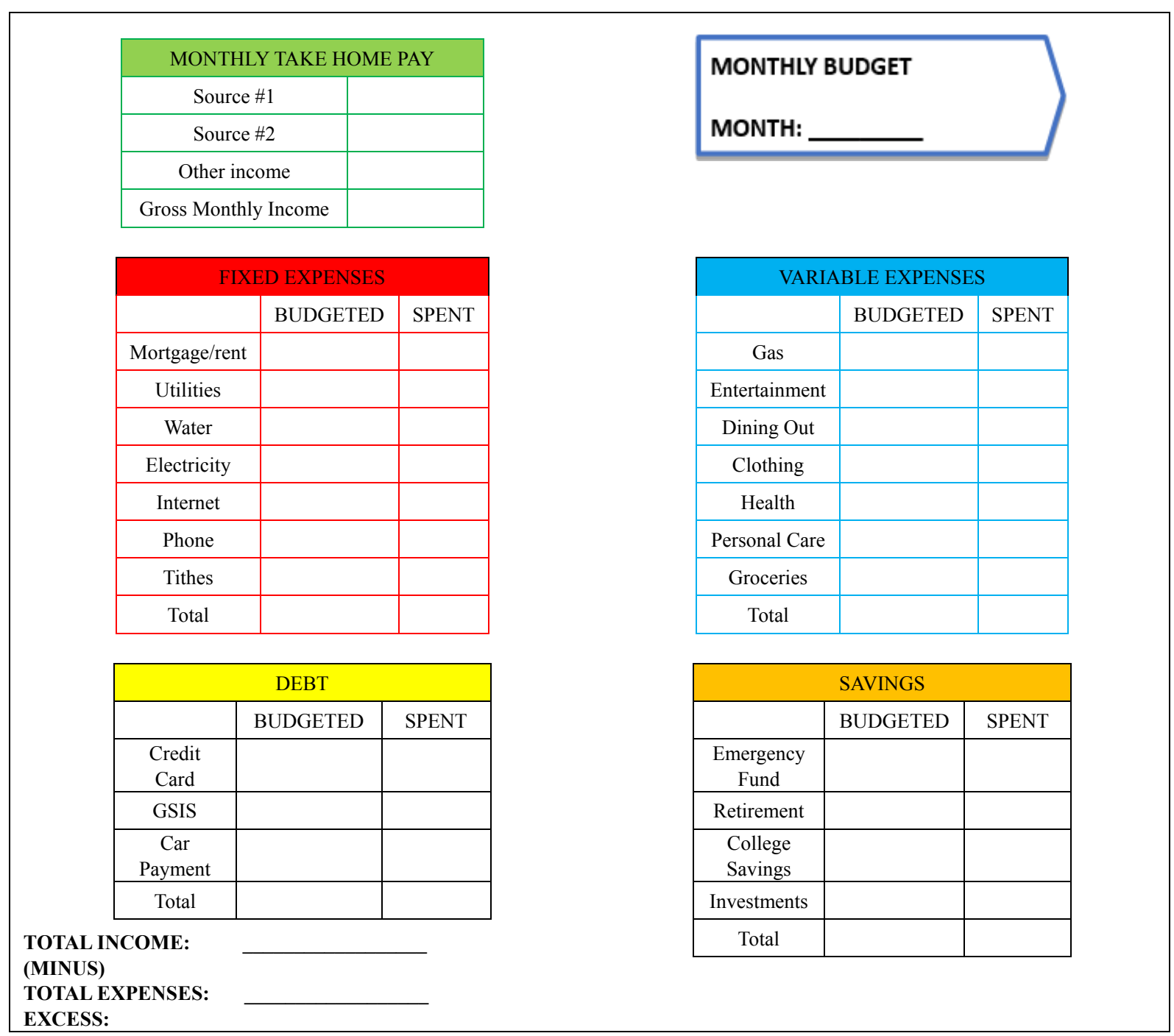


Table 3. Financial Goals and Plan of Actions Template

\begin{tabular}{|c|c|c|}
\hline $\begin{array}{l}\text { Investment } \\
\text { Assets }\end{array}$ & Amount in PhP & \\
\hline $\begin{array}{c}\text { Cash and } \\
\text { equivalent }\end{array}$ & & \\
\hline $\begin{array}{l}\text { Residential } \\
\text { Property }\end{array}$ & & \\
\hline Real Estate & & \\
\hline Total Assets & & \\
\hline \multicolumn{3}{|c|}{ Financial Goals } \\
\hline Goals & Target Year & $\begin{array}{c}\text { Amount of Money } \\
\text { Needed in Present Terms }\end{array}$ \\
\hline \multicolumn{3}{|l|}{ Retirement } \\
\hline \multicolumn{3}{|l|}{$\begin{array}{l}\text { Child's } \\
\text { education }\end{array}$} \\
\hline \multicolumn{3}{|l|}{$\begin{array}{c}\text { Child's } \\
\text { Marriage }\end{array}$} \\
\hline \multicolumn{3}{|l|}{ Dream Vacation } \\
\hline \multicolumn{3}{|l|}{ Dream Car } \\
\hline \multicolumn{3}{|c|}{ Plan of Action } \\
\hline Particulars & $\begin{array}{l}\text { Monthly } \\
\text { Savings }\end{array}$ & $\begin{array}{c}\text { Recommended Monthly } \\
\text { Savings }\end{array}$ \\
\hline \multicolumn{3}{|l|}{$\begin{array}{l}\text { Net Take Home } \\
\text { Pay (A) }\end{array}$} \\
\hline \multicolumn{3}{|l|}{$\begin{array}{c}\text { Household } \\
\text { expenses }\end{array}$} \\
\hline \multicolumn{3}{|l|}{$\begin{array}{l}\text { Insurance } \\
\text { Premium }\end{array}$} \\
\hline \multicolumn{3}{|l|}{$\begin{array}{l}\text { Total Outflow } \\
\text { (B) }\end{array}$} \\
\hline \multicolumn{3}{|l|}{ Savings (A-B) } \\
\hline $\begin{array}{c}\text { Actual } \\
\text { Investments }\end{array}$ & & \\
\hline
\end{tabular}

Financial Goals and Plan of Actions Template. Figure 3 presents the template for the family's financial goals and plan of actions which they must undertake to achieve these goals. This may help the teacher-parent's family in setting financial goals for every milestone of their lives like the college education of their children.

The first part of the Financial Goals and Plan of Actions Template is the investment assets of the family. This may include the cash and equivalent, residential property, real estate, and the like.

The second part is the financial goals. This includes the goals, the target year and the amount required to realize these goals in present terms. Some of the examples of milestones or goals are retirement, child's education, child's marriage, dream vacation, and dream car.

Finally, the last part is the plan of action that they should take for them to realize these goals. This may include the net take home less total outflow to identify the monthly savings, the insurance premiums, and the actual investments.

\section{Conclusions and Recommendations}

The study concluded that though economically challenged, teacher-parents and their spouses prioritized the education of their children. They believe that education is the best heirloom that they can give to their children. They also believe that this will help their children and their future families.

Based on the results of this study, the following recommendations were laid down: (1) The government should be aware of the financial challenges the teacher-parents face. They should implement an increase in the salary of teachers. The teacher-parents should not only prioritize the basic needs in their family expenditures. They also deserve to have recreational activities with their family. (2) The Department of Education, together with other departments and government agencies, must conduct seminars about financial literacy and financial management for teachers. This will help the teacher-parents to manage their salary well. (3) The Department of Labor and Employment must conduct livelihood training programs for teachers to help them expand opportunities to earn money especially during summer vacations. (4) The government should provide activities that will help the teacher-parents manage their time well. Their time should not be spent only on paper works and school activities. They need to spend plenty of their time with their children and spouse. (5) The school administrators should be supportive of the teacher-parents with regard to their activities as parents like attending PTA meetings, family day, and other child-related activities. (6) It is recommended that the proposed financial scheme be adopted by the teacher-parents and other types of parents to help them in the prioritization of the education of their children.

\section{REFERENCES}

[1] Denny, K., (2005). Do teachers make better parents? -the differential performance of teachers' children at school. Centre for Economic Research

[2] The 1987 Constitution of the Republic of the Philippines Article XIV | Official Gazette of the Republic of the Philippines.

[3] Philippines. (2016). Republic Act No. 10931 An Act Promoting Universal Access to Quality Tertiary Education by Providing for Free Tuition and Other School Fees in State Universities and Colleges, Local Universities and Colleges and State-Run Technical-Vocational Institutions, Establishing the Tertiary Education Subsidy and Student Loan Program, Strengthening the Unified Student Financial Assistance System for Tertiary Education. Retrieved form https://www.lawphil.net/statutes/repacts/ra2017/ra_10931_ 2017.html

[4] Philippine Development Plan 2017-2022 Abridged Version retrieved from http://www.neda.gov.ph/wp-content/upload s/2018/01/Abridged-PDP-2017-2022_Updated-as-of-0105 2018.pdf 
[5] Parks, M. W., (2006). Multicultural Perspectives, National Association for Multicultural Education

[6] Stern, B.S. \& Riley, K. L. (2002). Historical Legacy Linking Harold Rugg and Social Reconstructionism to "Authenticity" in Theory and Practice. Curriculum and Teaching Dialogue Vol. 4, No. 2, 2002, pp. 113-121.

[7] Murphy, J. F., \& Tobin, K. J. (2011). Homelessness comes to school: how homeless children and youths can succeed. Phi Delta Kappan, 93(3), 32-37.

[8] Pungello, E. P., Iruka, I. U., Dotterer, A. M., Mills-Koonce, R., \& Renznick, J. S. (2009). The effects of socioeconomic status, race, and parenting on language development in early childhood. Developmental Psychology, 45 (2), 544.

[9] Neubeck, K. J., Neubeck, M. A., \& Glasberg, D. S. (2007). Social Problems: A Critical Approach, 5th Edition. Mc-Graw Hill. 1221 Avenue of the Americas, New York.

[10] Al-Matalka F. (2014). The Influence of Parental Socioeconomic Status on their Involvement at Home. International Journal of Humanities and Social Science Vol. 4. No. 5

[11] Vellymalay, Suresh Kumar N (2012a). Parental Involvement at Home: Analyzing the Influence of Parents' Socioeconomic Status. Studies in Sociology of Science Vol. 3, No. 1, 2012, pp. 1-6.

[12] Republic Act No. 4670 (1966). The Magna Carta for Public School Teachers Retrieved from https://awphil.net/statutes /repacts/ra1966/ra_4670_1966.html

[13] Philippines. (2016). Executive Order No. 201, s. 2016 Modifying the Salary Schedule for Civilian Government Personnel and Authorizing the Grant of Additional Benefits for Both Civilian and Military and Uniformed Personnel. Retrieved from https://www.officialgazette.gov.ph/2016/0 2/19/executive-order-no-201-s-2016/

[14] Llego, M. A., (2019) 2019 Public School Teachers Salary in the Philippines. Retrieved from https://www.teacherph.com/public-school-teachers-salary/

[15] Bersales, L. G. S., (2019). Proportion of Poor Filipinos registered at 21.0 percent in the First Semester of 2018. Retrieved from http://www.psa.gov.ph/poverty-press-relea ses/nid/138411

[16] Bersales, L. G. S., (2018). Filipino Families are Most Deprived in Education. Retrieved from http://www.psa.gov.ph/poverty-press-releases/nid/136930

[17] Malipot, M. H. (2017). Why public school teachers tend to overborrow. Manila Bulletin. Retrieved from https://news.mb.com.ph/2017/10/31/why-public-school-tea chers-tend-to-overborrow/

[18] Mateo, J. (2017). Public school teachers' accumulated debt reaches P300 B. Philstar Global. Retrieved from https://www.philstar.com/headlines/2017/10/27/1753286/p ublic-school-teachers-accumulated-debt-reaches-p300-b

[19] Lopez, E. C. (2018). Is Financial Literacy the Answer to
Public School Teachers' Debt Woes?. Entrepreneur Philippines. Retrieved from https://www.entrepreneur.com .ph/news-and-events/is-financial-literacy-the-answer-to-pu blic-school-teachers-debt-woes-a00178-20180531

[20] Kenton, W. (2019). Financial Literacy. Retrieved from https://www.investopedia.com/terms/f/financial-literacy.as $\mathrm{p}$

[21] BSP Partners with DepEd and BDO Foundation To Promote Financial Education in Schools retrieved from https://www.bsp.gov.ph/SitePages/MediaAndResearch/Me diaDisp.aspx?ItemId=4599

[22] Philippines. (2015). Republic Act No. 10922Economic and Financial Literacy Act. Retrieved from https://www.lawphil.net/statutes/repacts/ra2016/ra_10922_ 2016.html

[23] Philippines. (2014). Republic Act No. 10679 An Act Promoting Entrepreneurship and Financial Education Among Filipino Youth. Retrieved from https://www.officialgazette.gov.ph/2015/08/27/republic-ac t-no-10679/

[24] Malipot, M. H. (2018). Briones reiterates importance of financial literacy to both learners, teachers. Retrieved from https://news.mb.com.ph/2018/11/30/briones-reiterates-imp ortance-of-financial-literacy-to-both-learners-teachers/

[25] Occupational Outlook Quarterly Summer (2010). Education pays: More education leads to higher earnings, lower unemployment. Retrieved from https://www.bls.gov/career outlook/2010/summer/oochart.pdf

[26] Machlup, F. (1982). Issues in the Theory of Human Capital: Education as Investment. The Pakistan Development Review. Vo. XXI, No. 1.

[27] Pindyck, R. S. \& Rubinfield, D. L. (2013). Microeconomics, 8th Edition. Pearson Education, Inc. U. S. A.

[28] Synder, C. M. \& Nicholson, W. (2010). Microeconomic Theory: Basic Principles and Extensions, 11th edition. Cengage Learning, 2012.

[29] Goode, D. (1976) The Noblest Profession in the World, Improving College and University Teaching, 24:4, 195, DOI: $10.1080 / 00193089.1976 .9927353$

[30] Miller, Z. (2019). Elizabeth Warren created a simple budgeting system that's still popular today. Here's what you need to know about it retrieved fromhttps://www.bankrate.com/personal-finance/smart-mo ney/elizabeth-warren-50-30-20-budget/

[31] Warren, E., \& Tyagi, A. W. (2006). All Your Worth: The Ultimate Lifetime Money Plan. New York: Free Press.

[32] Yates, S. (2017). Money Management for Student Athletes Transitioning to Professional Sports: How to Plan When Cash Flows are Uneven and Uncertain. The Sport Journal. retrieved fromhttps://thesportjournal.org/article/money-ma nagement-for-student-athletes-transitioning-to-professional -sports-how-to-plan-when-cash-flows-are-uneven-and-unc ertain/\#post/0 